INTERMARUM: history, policy, culture. - Issue 6.

UDC 342.56:94(477.4)«1797/1831»

DOI 10.35433/history.11191

Shevchuk Andrii,

$\mathrm{PhD}$ in History, Associate Professor at the Department of World History, Zhytomyr Ivan Franko State University shevchuk.istor@gmail.com

ORCID: https://orcid.org/0000-0001-9023-5214

\title{
SUPREME COURTS OF THE RIGHT-BANK UKRAINE (1797-1831): TRADITIONS OF THE POLISH AND LITHUANIAN COMMONWEALTH AND IMPERIAL EXPERTISE
}

\section{Abstract}

The purpose of the research is predetermined by studying the process of establishment and the organization principles of supreme courts operation, performing auditing and appeal functions in the Right-Bank Ukraine. One of primary goals of the article is to establish the verge of concessions and compromises the Russian officials were ready to reach in the judicial sphere in order to regain the allegiance of the Polish nobility. The chronological and territorial borders of the research encompass territories of the former "kresy" in the period from the end of the XVIII century till the first third of the XIX century.

The methodology of the research is based on the principles of scientificity, objectivity, historicism, systematicity. In order to reach the stated goals, appealing to the comparative method the article provides an analysis of peculiarities of the Russian judicial system preserving elements of the legal expertise of the Polish-Lithuanian Commonwealth due to a sufficient imperfection of its own one. The historical-systemic, functional and historicalcomparative methods provide for investigation of the supreme courts' establishment and operation processes, illustration of situational flexibility of the supreme powers in meeting requirements of the local elite. The article analyses the efficiency level of the judicial authority activity and its assessment by the Russian powers, local officials and the Polish nobility. The scientific novelty is attained by studying the stages of establishment and organization of the supreme courts' operation in the process of developing the relationship between the Russian Empire and the former «kresy» in the context of adapting 
IНТЕРМАРУМ: історія, політика, культура. - Вип. 6. ISSN 2518-7694 (Print)

judicial systems. There are certain facts of situative flexibility of the supreme powers in the judicial sphere allowing to minimize the social and political tension in the region, provided in the article.

Re-establishment of the first-instance courts, the Polish language and the Third Statute of the Grand Duchy of Lithuania by Paul I became a sufficient reason to reach consent in the relationship between the Polish szlachta and the Russian authorities. The central administration held a flexible policy in the judicial sphere to ensure allegiance of the local Polish elite, which both conciliated the local nobility with the Russian leadership and preserved power over the serfs. The Empire's intention was to make corrections in the judicial system operation in order to minimize the social and political tension by means of establishing governorate supreme courts. The Polish elite comprised the vast majority in the courts' staffing. However, a head and three chairmen, chosen by the szlachta to each department for a three-year term, were to be approved by the power and controlled by the appointed advisors and secretaries. The requirements of the Polish noblemen in secondary issues, namely bilingualism, judicial proceedings and providing vacations, were satisfied, though the governorate judicial system was subordinated to the supreme courts. For successful operation of the system, if needed, there were additional temporary departments created. Providing peace was the main marker of the domestic policy success, the judicial system being on the right way. However, the central power policy in the region was changed after the November Uprising of the 1830-1831.

Key words: supreme courts, Russian Empire, Right-Bank Ukraine, governorate supreme court, judicial system, Polish nobility (szlachta), imperial allegiance.

Introduction. The XVIII century became for the Russian Empire a period of a rapid territorial development, which was a symbol of a flourishing state at that time. The large-scale changes initiated by Paul I made it possible for the country to become a regional leader. The policy of transformations was further successfully developed by Catherine II. The empress offered a Europe-oriented program which was partially realized under her rule. The judicial reform was aimed at establishing an estate system with elected officials and a great number of instances. However, this system, being foreign to the Russian experience, was familiar to the territories incorporated from the Polish-Lithuanian Commonwealth for more than two centuries. Another factor, significant for the empress, was a rapid adaptation of all spheres in the adjoined 
INTERMARUM: history, policy, culture. - Issue 6.

territories to the imperial pattern. In order to reach this goal Catherine II was close to sacrifice allegiance of the local nobility.

Paul II required centralization and bureaucratization that together with organization of different spheres of life could ensure a positive dynamics of development. His policy was characterized by a larger share of deliberation: for the sake of the primary goal he was ready for making concessions in the minor issues. It is from this perspective his reforms of the judicial system, handed to the local elite, should be considered. Re-establishment of the judicial structure of the PolishLithuanian Commonwealth (district and chamberlain's courts), noninterference in the particular affairs of the szlachta, revival of the Polish language and the Third Statute of the Grand Duchy of Lithuania persuaded the Polish nobility that «the old times» were back. However, this «move forward» referred to the judicial power and the first-instance courts only. In order to preserve control, a great number of new institutions was established, the leading role being performed by the governorate supreme courts. «Flirtation» with the elite was further maintained in the policy of Alexander I, and the primary task of the judicial system was to comfort the szlachta.

The problem of the supreme courts' operation in the Right-Bank Ukraine in the end of XVIII - beginning of the XIX century is not sufficiently presented in the historiography. The possible reasons, as we may assume, are an inappropriate preservation of the archive documents and a high labour intensity in studying the problem. The object being relevant to both history and jurisprudence makes investigation of the problem more complex. Consequently, the materials devoted to functioning of the judicial structures contain numerous mistakes repeating in every other research.

At the same time, activity of the supreme power in the region under analysis was included to the focus of scientific attention. A fundamental monograph by $\mathrm{M}$. Dolbilov provides an analysis of the ethnic and confessional policy of the supreme power under the rule of Alexander II in the territories of Lithuania and Belarus incorporated from the PolishLithuanian Commonwealth. The author stresses that the Empire possessed a vast territory and an extremely diverse ethnic, confessional and social content. There were various institutions and administration procedures applied to govern the remote regions varying from 
IНТЕРМАРУМ: історія, політика, культура. - Вип. 6.

dramatically archaic to provocatively innovative ones. In the meantime the imperial power was constantly accommodating to new situations, remodelling relationship with the local communities, searching for opportunities to agree on their interests and its own priorities (Dolbilov, 2010, p. 18). L. Gorizontov emphasizes that the policy of the power in the incorporated territories was defined, first and foremost, by the Polish issue. Seen from the position of the Russian domestic policy, it concerned the comprehensive integration of the former lands of the Polish-Lithuanian Commonwealth to the imperial body and making the Polish people devoted servants of the ruling dynasty; dramatically, the attempt failed. The author's attention is also largely concerned with the repeated reconsideration of the administration system of the Western outskirts. The scholar insists upon a noticeable strengthening of the positions regarding the Polish as early as in 1820-ies, but until the November Uprising of the 1830-1831 a substantial turn was not defined (Gorizontov, 1999, p. 7-8).

The Austrian scholar A. Kappeler considers the attached territories of the Polish-Lithuanian Commonwealth as a body foreign to Russia. The author presents an opinion that the Polish issue destabilized the autocratic Empire. The major purpose under the rule of Catherine II was reaching homogeneity and unification, while Paul I tended to more traditional structures. The scholar explains the delay in forcing the integration by the Russian wars held in Europe until 1815. A. Kappeler concentrated his attention on the difficulties in establishing modus vivendi of the supreme powers with the local elite refusing to tolerate the loss of independence; the urban and rural citizens could not stand as partners to the Russian officials. Proceeding with the experience of previous expansive measures, Russia established cooperation with the regional elite and the allegiant Polish noblemen were accepted by the imperial nobility and became members of local authorities. 1820-ies brought discord into the Russian-Polish relationship and the November Uprising in 1830-1831 initiated the dramatic changes.

The American historian T. Snaider in his research, devoted to the phenomenon of a modern nation, draws attention to the fact that almost 10 percent of the Right-Bank Ukraine governorates were represented by the Polish szlachta, the vast majority of which lost its privileges after the November Uprising. The Russian authority turned them in the legal 
INTERMARUM: history, policy, culture. - Issue 6.

aspect from the poor noblemen into the poor peasants, and the only category managing to avoid the declassing policy was represented by large landowners (Snaider, 2012, p. 151). Thus, it was obvious that the power had to reckon with the opinion of such a numerous group.

The Russian scholar L. Pisarkova points out that the reformation program held by Paul I totally transformed the essence of the judicial system losing its estate and elective character, major in the reform of 1775. Re-establishment of privileges and national specifics in the judicial system organization in the peripheral governorates, preserving the supreme power control over the administrative and finance management, was in the focus of attention (Pisarkova, 2007, p. 498, 501). Conclusions made by the scholar are similar to the ideas expressed by M. Klochkov. Making a positive assessment of the reform held by Catherine II in 1775, he criticizes the empress for complexity of the judicial system and the lack of proportionality in its representation by the nobility. Under the rule of Paul I, despite the fact that the previous rights and privileges were re-established, the real power was concentrated in the hands of the governor and the governorate administration (Klochkov, 1916, p. 407-413, 417-418, 426-427).

N. Karnishyna brings to attention the diversity of legal, state and administrative forms in the Russian Empire, the complexity and the multiplicity of the outskirt administration functioning within a single bureaucratic system. The author emphasizes that the November Uprising of 1830 promoted the administrative and legal unification of the Western counties (Karnishyna, 2012, p. 14). N. Shcherbak outlines that the period under the rule of Paul I was marked by activization of the Polish presence in the state administrative institutions, whereby preferably the poor quit-rent noblemen mastering the Russian language and paperwork administration applied for state service positions. The scholar stresses that the procedure of election of judicial establishments officials was under governors' control (Shcherbak, 2017, p. 290). Characterizing the process of integration of the Polish aristocracy into the Russian imperial system, V. Pavliuk comes to a conclusion that the influence of the elite was preserved until 1831 not only concerning the property, but also the control over public life in the agrarian relationship and at the local level through the election system. Besides, the author provides examples of aristocracy confronting the Russian leadership 
IНТЕРМАРУМ: історія, політика, культура. - Вип. 6.

(Pavliuk, 2010, p. 160-163). The Ukrainian law scholar O. Ilin, assessing the measures taken by Paul I, concludes that the emperor's goal was not the return to the old times but creating a more centralized and dependent judicial system regarding some of the local traditions. The author insists that these changes were short-term ones and failed to make an essential influence on the further evolution and transformation of the judicial system (Ilin, 2016, p. 26-27). The research conducted by $\mathrm{S}$. Yesiunin focuses on the issue of advocacy in the Podil Supreme Court. The author provides analysis of the procedure of gaining positions and characterization of the advocacy staffing, concentrates on the measures taken by the power in order to eliminate this traditional judicial instance of the Polish-Lithuanian Commonwealth (Yesiunin, 2016, p. 242-252).

The aim of the research is studying the process of establishment and the organization principles of the supreme courts' operation, performing auditing and appeal functions in the Right-Bank Ukraine. One of the primary goals of the article is to establish the verge of concessions and compromises the Russian officials were ready to reach in the judicial sphere in order to regain the allegiance of the Polish nobility. In order to reach the stated goals, appealing to the comparative method the article provides an analysis of the peculiarities of the Russian judicial system preserving the elements of the legal expertise of the Polish-Lithuanian Commonwealth due to a sufficient imperfection of its own one. The historical-systemic, functional and historicalcomparative methods provide for investigation of the supreme courts' establishment and operation processes, illustration of the situational flexibility of the supreme powers in meeting the requirements of the local elite. The article analyses the efficiency level of the judicial authority activity and its assessment by the Russian powers, local officials and the Polish nobility. The scientific novelty is attained by studying the stages of establishment and organization of the supreme courts' operation in the process of developing the relationship between the Russian Empire and the former «kresy» in the context of adapting judicial systems. There are certain facts of situative flexibility of the supreme powers in the judicial sphere allowing to minimize the social and political tension in the region, provided in the article. 
INTERMARUM: history, policy, culture. - Issue 6.

The chronological and territorial borders of the research encompass the territories of the former "kresy" in the period from the end of the $18^{\text {th }}$ century till the first third of the $19^{\text {th }}$ century.

The outline of the research. Taking power and striving for centralization and bureaucratization, Paul I initiated reformation in different spheres including the judicial system. The judicial structure suffered simplification and lost its estate character by means of abolishing the upper zemstvo court established for the nobility, the governorate magistrate for the merchants and the upper and lower estate courts for the state peasants, and the chambers for civil and criminal cases were restructured. According to the Charter signed on December, 311796 a district court was created in every district, its jurisdiction spreading over the whole population of the district, except for townmen subordinate to the magistrates and the town halls (also known as rathauses). At the governorate level there were appeal court chambers created, falling into two departments of criminal and civil cases (Speranskyi, 1830e, p. 396). However, on December, 121796 the emperor held a new administrative and territorial division creating two categories of governorates with "administration on the general basis" and "peculiar rights and privileges", the latter category including Kyiv, Volyn and Podil governorates (Speranskyi, 1830a, p. 229-230). As far as the judicial system was chosen as a means of convergence with the local elite, the re-established district courts (whereby the original Polish name powiatowy instead of the Russian uezd to denote the word district was used), chamberlain courts, magistrates and the town halls were to represent the first instance. Though, Paul I required a total control and thus could not leave the judicial system alone, establishing a system of mutual control both over the first instance courts and the controlling bodies, namely the Volyn outer court (1798-1801) (Shevchuk, 2018a), governorate supreme courts (1797-1831) and the fiscal institute (1799) (Shevchuk, 2018b).

According to the Charter of December, 311796 there were Kyiv, Volyn and Podil supreme courts established in the Right-Bank Ukraine, each divided into two departments of criminal and civil cases. Each department consisted of a head (fifth class), an advisor (fourth class) and three chairmen (Speranskyi, 1830e, p. 397-398). In order to ensure the inner control over the instance's operation, the supreme power 
IНТЕРМАРУМ: історія, політика, культура. - Вип. 6.

appointed advisors (Speranskyi, 1830a, p. 728). The heads and the chairmen were elected by the governorate nobility with the further approval by the Senate and the governors correspondingly.

The governorate supreme courts were completely new instances, important to say, having a conditional analogue - the Crown Tribunal, the highest appeal instance of the estate nobility courts of the PolishLithuanian Commonwealth, spreading its jurisdiction over Lesser Poland and Ukrainian voivodeship. The paperwork for the Ukrainian lands was provided in Ruthenian language. The Tribunal consisted of justices of the peace ( 27 until the second half of the $17^{\text {th }}$ century, later 50 ) and clerical judges ( 6 until the second half of the $17^{\text {th }}$ century, later $-8)$. The first ones were elected annually in September in the nobility sejmiks, each voivodeship represented by 1-2 members. They performed their obligations for a year starting from November. The judicial proceedings were presided by a marshal chosen among the members. The clerical members of the Tribunal were elected by the episcopal councils headed by a president chosen from the delegates. The Tribunal proceedings as a rule were held in spring and summer. If the judges were unable to produce unanimous decision in a certain case, the third attempt was followed by a mere majority of votes. If there was an equal number of votes, the case was submitted to the Sejm. The sentences and decrees of the Tribunal were approved by three judges' signatures and sealed. In the course of 1764-1772 the Tribunal's meetings were held in Lublin and Lviv. After the First Partition of Poland the Tribunal continued its operation holding the meetings in Lublin only. The final session of the Tribunal was held in 1794 (Hurbyk, 2009, p. 382).

The main document being the basis of the supreme courts' functioning was the Senate decree dated September, 11 1797. The reason for it was the report submitted by the Prosecutor General of Minsk, Volyn and Podil governorates O. Bekleshov, highlighting problems in the establishment and operation of the judicial institutions. The language issue was of the most serious concern for the Russian officials. As far as according to the Charter a translator, an advisor and a secretary appointed by the Crown were prescribed in the staffing of the court, the documentation on the cases was presented in two columns in the Polish language on the left, and the Russian - on the right. 
INTERMARUM: history, policy, culture. - Issue 6.

Translation was required by the governorate prosecutors and senators receiving the cases for consideration and approval.

The official suggested that all the books registering incoming and outgoing documents, as well as reports and mailing with the institutions which did not use the Polish language, were presented in Russian. Moreover, there was a procedure which presupposed that the firstinstance courts had to submit cases of criminal suspects from district courts to the supreme court together with an extract (a formal copy indicating the corresponding laws) and suggested measures of punishment. The supreme court provided its own extract and sent it to the Senate. After accepting an appeal of first-instance court decision, the civil department had to compose an extract and send it to the Senate together with translation of the documents in Russian.

The issue concerning vacations was also mentioned in the report. Though O. Bekleshov considered that supreme courts were patterned after the Russian chambers, he couldn't resolve the problem of vacation duration. In the Polish tradition vacations lasted for four months. The supreme power satisfied all the Prosecutor General's suggestions and introduced a ban for the officials to be provided with a four-month vacation (Speranskiy, 1830a, p. 727-732). The power of the decree also concerned the Kyiv governorate. On December, 291798 the hearing presented to the department the Senate's decree on introduction of the bilingual (Polish and Russian) paperwork management conducted on the basis of O. Bekleshov's report (Central State Historical Archives of Ukraine in Kyiv - F. 484. Op. 2. D. 13. L. 1).

The supreme power provided the institute of the supreme courts with exceptional authority. On November, 181797 the Podil governorate leadership obliged all the first-instance courts (district, chamberlain and magistrate courts) to perform instructions of the supreme court and to submit regular reports on their operation (Central State Historical Archives of Ukraine in Kyiv - F. 1582. Op. 1. D. 1. L. 27). Necessity to provide monthly reports on dangerous criminals and current matters was emphasized by the direction to submit reports dated March, 121798 (Central State Historical Archives of Ukraine in Kyiv F. 1582. Op. 1. D. 1. L. 68). The evidence of a high status of the supreme judges was the fact that the governorate administration addressed them with recommendations but not the directions as in the 
IНТЕРМАРУМ: історія, політика, культура. - Вип. 6.

case with other judicial institutions (State archive of Rivne region F. 550. Op 1. D. 3. L. 18).

The overloading of the supreme courts with cases provoked the power's concern, resolving the problem with cases by means of establishing new temporary departments. On July, 201808 a temporary department by the Volyn supreme court was created. The terms of its operation depended on time needed to hear 618 cases and the newly elected head and chairmen were to consider current proceedings (Speranskiy, 1830c, p. 418). Establishment of an analogous department by the Podil supreme court on November, 11 affirmed the systemic character of workload (Speranskiy, 1830c, p. 679).

There were still a lot of cases to deal with, thus in 1820 the senator and secret advisor Baranov from the Volyn governorate informed about numerous civil and criminal cases unheard in the first department of the Volyn supreme court. As far as such situation increased the terms of suspects' incarceration, there was a direction to create a temporary department comprised by the former court members and an advisor from the Crown appointed by the Senate (with full pay) and to elect members to the first department. The cases were divided between the temporary departments which were obliged to operate until the complete resolution of the problem (Speranskyi, 1830d, p. 349-350). The cardinal improvement of the situation with the cases was not reached, that was proved by adding one secretary to each of the departments with pay of 350 roubles per year in 1821 (Speranskiy, 1830d, p. 957).

Nevertheless, even the staff expansion was inefficient in resolving the problem. The operation of the Volyn supreme court was subjected to constant remarks made by the power. The commander-in-chief of the Lithuanian separate corps, tsesarevich Konstantin Pavlovich announced that of April, 21825 there were few cases left to be heard in the temporary department created in 1820. The criminal department then shared a half of the cases with the temporary department, however it lead to a five-time increase in the number of cases. As a consequence, the supreme power punished the officials and the secretary of the criminal department. From then on, they had to hear all the cases without pay, proceedings were held twice a day without a right for vacation and a permission to leave the workplace during the working day. To hear the current cases a new criminal department was 
INTERMARUM: history, policy, culture. - Issue 6.

established. The Volyn civil governor and the governorate prosecutor were responsible for controlling consideration of the cases and obliged to provide monthly reports to the Senate and the minister of justice (Complete collection of laws of the Russian Empire, 1830, p. 314-315).

As for the work schedules, the analyzed proceeding protocols certify that the working day lasted from 9 a.m. till 2 p.m. (Central State Historical Archives of Ukraine in Kyiv - F. 484. Op 1. D. 82. L. 5, 8). The more topical issue was concerning the terms of proceedings. If the proceedings in the Crown Tribunal mentioned above were held in spring and summer, the Russian administration tended to systemic labour character, that could be achieved by everyday work without providing vacations. On the other hand, operation in the following manner would push the szlachta away from holding positions of a head and chairmen.

In his report of 1797 O. Bekleshov requested what to do with vacations for the elected noblemen. He suggested that they had the same rights as the first-instance court officials. Initially the Senate's decree stated that vacations had to be provided according to the Russian laws, as far as supreme courts were created on the basis of chambers implemented under Catherine II (Speranskiy, 1830a, p. 732). In nine months on June, 261798 the judicial institutions received from Podil governorate administration O. Bekleshov's direction dated September, 231797 on constant presiding of the supreme court. The major argument provided was that «they were the former upper zemstvo court officials» (Central State Historical Archives of Ukraine in Kyiv F. 1582. Op 1. D. 1. L. 91-91; State archive of Vinnytsia region F. 514. Op. 1. D. 1. L. 114). However, the necessary corrections were made in an instant. They were obviously connected with the emperor's position insisting on the Polish nobility preserving their privileges in the judicial system. The lack of information resulted in the supreme courts being obliged to report on the ways to resolve the vacation issue employed before the incorporation (Central State Historical Archives of Ukraine in Kyiv - F. 1582. Op 1. D. 1. L. 69-69). The following direction was to provide a four-month vacation for the chairmen elected by the Polish nobility (Central State Historical Archives of Ukraine in Kyiv - F. 1582. Op 1. D. 1. L. 91-91; State archive of Vinnytsia region - F. 514. Op. 1. D. 1. L. 114). According to the decree of August, 29 1798 it was divided into two parts from July, 20 to August, 20 and 
IНТЕРМАРУМ: історія, політика, культура. - Вип. 6.

December, 20 to February, 20. At the same time, the right to take vacations was conferred on heads and advisors (although the latter were officials appointed by power - author's note) except for the supreme courts' chairmen of Podil, Volyn and Minsk governorates (Speranskyi, 1830b, p. 358-359; Central State Historical Archives of Ukraine in Kyiv - F. 1582. Op 1. D. 1. L. 126; State archive of Vinnytsia region F. 514. Op. 1. D. 1. L. 151).

Providing regular proceedings on cases of the imprisoned, accused of committing serious crimes, was of great importance for the supreme power. There was a special procedure developed, presupposing the constant presence of a head, an advisor and a chairman, even during vacation period (Central State Historical Archives of Ukraine in Kyiv F. 1254. Op 1. D. 912. L. 3). As far as from July, 20 to September, 20 1812 the civil department of the Kyiv supreme court was out of operation, consideration and resolution of cases from July, 20 to August, 20 was provided by the head of this department Zaharzhevskiy, and from August, 20 to September, 20 - by the head of the civil department Proskura. The advisor Zuiev was not engaged in the procedure due to health matters and five-year accrued vacation. His post was temporarily occupied by the advisor of the civil department Bashutskyi. As for the chairmen, Obukhovskiy was obliged to work the full term, while Pidvysotskiy and Prushinskiy were given a vacation. Such labour division was to be coordinated by the Senate and approved by governorate administration (Central State Historical Archives of Ukraine in Kyiv - F. 484. Op 1. D. 82. L. 674).

There was also a procedure providing a chairman with an advance vacation. On March, 221799 the civil department of the Kyiv supreme court considered a request of the chairman O. Holovenskyi to be provided with an advance eight-day leave for his home in Bohuslav district. There was a decision accepted to satisfy the request as there were the head, the advisor and the chairman left in the department who were able to settle the cases. A corresponding recommendation was submitted to the civil governor to issue a final decision referring to the case (Central State Historical Archives of Ukraine in Kyiv - F. 484. Op 1. D. 9. L. 337).

The main feature of the judicial system operation efficiency for the supreme power was ensuring peace in the region. The most active 
INTERMARUM: history, policy, culture. - Issue 6.

champions of the power interests in the Right-Bank Ukraine were the governorate prosecutors. Involving of the supreme court chairmen became a subject of a serious conflict in 1800 between the appointed Kyiv prosecutor Matianin and the governor V. Krasno-Milashevych. Less than two months after appointment to the position, the prosecutor submitted a report to the Prosecutor General P. Obolianinov on an unlawful consideration of cases in the courts. The main reason, as seen by the prosecutor, was an unjust involving of the governorate administration advisors and the supreme court chairmen in hearing the officials' cases. Up to five persons were involved in the examination proceedings, although the cases were to be considered by the criminal department of the Kyiv supreme court. Suspension of the officials galvanized the operation of the instance, but still, the received response was an evidence of the supreme power deference to the governor: it was mentioned that in extraordinary and exceptional cases the supreme court could deliver its officials to participate in the cases. In such situations the prosecutor had to report to the governor (Central State Historical Archives of Ukraine in Kyiv - F. 1254. Op 1. D. 476. L. 1, 2-2, 3, 4).

An analogous situation took place in 1802, when the governor of Kyiv Hudyma submitted a complaint to the Russian capital revealing the violation of the judicial procedure by the civil department of the supreme court. He found out two unfulfilled decrees of the Senate on submission of the cases for appeal. The main reason for galvanization was the Polish language usage. The necessary extracts were compiled not before the proceeding but after it, and only for the cases sent to the Senate. If the parties were satisfied by the sentence, the extract was neglected at all. Due to his observation, the Polish language only was used, thus the cases weren't submitted to the Senate because the translations weren't provided. The Russian language was used only for mailing concerning secondary issues (Central State Historical Archives of Ukraine in Kyiv - F. 1254. Op 1. D. 535. L. 2-2, 3). Nonetheless, the Senate sided with the department believing there was nothing bad in the Polish judiciary, as the main requirements were paying the fees and making agreements on the stamped paper. The civil governor of Kyiv M. Korobyin also confronted the prosecutor's position, reporting that the civil department was successfully resolving the cases and there were no complaints concerning its operation, delaying the cases or adopted 
IНТЕРМАРУМ: історія, політика, культура. - Вип. 6.

decisions. Thus, there was a suggestion for the court to continue the resolution of the cases due to the existing laws (Central State Historical Archives of Ukraine in Kyiv - F. 1254. Op 1. D. 535. L. 6-6).

The new governors could not understand the operation mechanism of the supreme courts which were different from analogous institutions in other regions, and that resulted in grave incidents. After the appointment in 1805, the governor of Volyn M. Volkonskyi held an inspection of the state establishments. Due to absence of a full staff in the criminal department there was a logical question: who allowed the former members to leave and the recently appointed ones not to hold the position? Consequently, the criminal cases of the prisoners weren't heard for a month. In the explanation provided by the government it was indicated that on July, 20 there was drawing of the lots held in the general assembly of both departments. But the appointed members of the civil department (the head Korzhenevskyi and the chairman Stetskyi) didn't take powers and start the work. Finally in 1806 the Ministry of Justice ordered the governorate administration to make the guilty provide an explanation of disrupting the working process and to punish them according to the law (Central State Historical Archives of Ukraine in Kyiv - F. 1254. Op. 1. D. 563. L. 1-1, 4).

In 1807 the Polish military governor I. Essen made complaints to the minister of justice of his subject, the governorate prosecutor and outer court advisor Pohorzhelskyi who failed to control cases of the imprisoned. Despite the fact that the criminal cases were to be heard in a month term, the prisoners were remanded in the criminal department of the Podil supreme court. In response the official explained that the reasons of delay were predetermined by the lack of clerks (the supreme leadership being informed about it thrice). That was his explanation for slow translating from the Polish and absence of extracts and sentences (only in one case a certificate from the Bratslav lower zemstvo court was expected). In other respects, the judiciary completely corresponded to the legislature (Central State Historical Archives of Ukraine in Kyiv F. 1254. Op. 1. D. 1018. L. 1, 2-3, 5).

In some cases the relationship between the supreme court members and the governorate prosecutors were complicated enough. In 1815 the Podil official informed the minister of justice D. Troshchynskyi about the absence of the criminal department head, prince F. Chetvertynskyi 
INTERMARUM: history, policy, culture. - Issue 6.

who was searched for in Yampil and Bratslav districts and finally found in Ostroh. The peculiar attention was addressed to the outer advisor of the same department V. Reva who was late for job from the vacation for eight days. However, he produced a certificate signed by two landowners (it took 90 versts to the district city) that his leg had been broken, but the prosecutor threatened to bring him to justice. The case had an unexpected resolution: the minister ordered the prosecutor not to be biased and stop "the senseless mailing" (Central State Historical Archives of Ukraine in Kyiv - F. 1254. Op. 1. D. 1522. L. 1-1, 7-7, 10). The chairmen's presence was contolled by governorate prosecutors who were provided with a corresponding monthly information. In July of 1812 the chairman of the criminal department of the Podil supreme court D. Yanishevskyi was absent from six proceedings. The prosecutor treated it as an own-will evasion for which a fixed payment had to be charged, thus he required the chairmen to provide a reason for his absence (State archive of Khmelnytsky region - F. 120. Op 1. D. 766. L. 11).

Again, in April of 1816 the chairmen of the criminal department of the Podil supreme court L. Pavskyi and the temporary department K. Izhytskyi were absent from April, 4 and April, 17 correspondingly to the end of the month. The latter was also absent until September, 20 of the same year that resulted in the delay of the temporary department operation. The governorate administration required explanations from the criminal department (State archive of Khmelnytsky region - F. 120. Op 1. D. 766. L. 34-35).

In some cases the local elite was discontented with operation of the supreme courts, offering projects of the judicial system reformation. On March, 141805 the nobility of the Volyn governorate considered the issues on operation of the judicial bodies and electing candidates for holding elective positions. In a month term the Volyn governorate marshal S. Vortsel addressed the minister of domestic affairs V. Kochubei requesting his permission to elect 24 chairmen to the supreme court for a one-year term. Moreover, the approval of former Polish conditions of the judges' activity and election of the court officials was discussed. However, the request wasn't satisfied (Barmak, 2007, p. 426). 
IНТЕРМАРУМ: історія, політика, культура. - Вип. 6.

The nobility of Volyn governorate went even further in its requirements after the French Invasion of Russia in 1812. After the news announcing the establishment of the Committee of the governorate landowners resentment, the prince K. Poninskyi submitted a letter addressed to the emperor containing complaints about the supply of horses, soldiers, wagons, provisions etc. during the previous war. It was mentioned that landowners paid taxes, fed soldiers, delivered wagons, provisions, firewood and many other things for free, thus, Alexander I could allow them to elect all the officials starting from the governor (like the Don Cossacks did). At the same time, together with the Russian officials the Polish szlachta representatives were suggested to be included into the Committee (Central State Historical Archives of Ukraine in Kyiv - F. 1254. Op 1. D. 1555. L. 3-4).

There were some curiosities occurring in the system. In 1816 the Senate received a ten-page letter from a collegiate registrar (of the lowest 14th rank in the Table of Ranks) S. Belianovskyi containing a project of the state and judicial power reformation. The author occupied position of a clerk in the district and supreme courts where the bribery flourished and clerks were of greater importance than judges. He witnessed many violations: the cases were delayed in years, the rich sued the property from the poor (the latter went bankrupt making payments and presents to judges, scriveners and clerks), the suspects could spend years in custody. The author believed there were any just and honest judge or official, their behaviour being explained by a desire to live a wealthy life. The supreme courts' advisors earned 600 roubles in assignation (documents certified payments in silver - author's note), and the urban life costed 10 thousand roubles. Belianovskyi suggested to abolish payments for the stamped paper, as far as money received wasn't enough to justify the expenses for the officials, and that would reduce their number in a quarter. The major means to fight bribery was election or appointment of wealthy landowners. According to his idea, the noblemen had to elect the district justices of the peace (holding in possession more than 200 serfs). If the election was failed more than thrice, the case would be submitted to the court (the guilty party would pay the costs). As seen by Belianovskyi, the number of governorates and districts had to be decreased by half, the officials reduced and the positions granted to the wealthy persons only. The suggested property 
INTERMARUM: history, policy, culture. - Issue 6.

qualification was as follows: governor -3 thousand serfs; advisor -1 thousand; secretary - 500; head of the supreme court - 2 thousand; chairman -1 thousand (Central State Historical Archives of Ukraine in Kyiv - F. 1254. Op 1. D. 1656. L. 1-6, 9). However, the letter remained a mere project.

Nicholas I accession to power signified a turn towards centralization and bureaucratization policy, putting aside the regional peculiarities. After the November Uprising was suppressed on October, 30 1831, all state establishments and official positions of the RightBank Ukraine received all-Russian names due to the named decree. The heads of the criminal chambers were appointed by the supreme power recommended by the Ministry of Justice and a temporary military governor. The advisors of the judicial chambers were approved by the Ministry of Justice (Complete collection of laws of the Russian Empire, 1831, p. 159-160).

Conclusions. Re-establishment of the Polish-Lithuanian Commonwealth judicial tradition by Paul I, manifested by reactivation of the first-instance courts, the Polish language and the Third Statute of the Grand Duchy of Lithuania, became a substantial reason for reaching consent in the relationship between the Polish szlachta and the Russian authorities. The central administration held a flexible policy in the judicial sphere to ensure allegiance of the local Polish elite, which both conciliated the local nobility with the Russian leadership and preserved the power over the serfs. Nevertheless, the Petersburg authorities could not leave the courts uncontrolled. The purpose of the state was to make corrections in the magistrate, district and chamberlain's courts operation by means of establishing governorate supreme courts of appeal. In order to reach minimization of social and political tension, the supreme power demonstrated a certain far-sightedness and readiness to take risks regarding the judicial system functioning and, correspondingly, regulation of Russian presence. The Russian policy in the judicial sphere was marked by operation of the criminal departments of Kyiv, Volyn and Podil supreme courts. They displayed general imperial problems in the outlined sphere and willingness to preserve the regional specifics.

Superficially, the staffing of the judicial instance confirmed domination of the Polish nobility: each of the two departments (of civil 
IНТЕРМАРУМ: історія, політика, культура. - Вип. 6.

and criminal cases) was represented by a head and three chairmen elected for a three-year term and appointed in the positions by the szlachta. The interests of the supreme power were protected by advisor and secretary, assigned by the power. The latter position was of peculiar importance, as far as under the conditions of formal judiciary much depended on the official's professionalism and the staff of clerks headed by him. To organize the operation of the supreme courts the practical experience of Minsk, Volyn and Podil governorates' general O. Bekleshov was taken into consideration, while he expressed flexibility in suggesting bilingualism in the supreme courts' operation, determining the judiciary procedure and accentuating the importance of the four-month vacation issue for the officials. After these secondary issues were regulated, the supreme power provided the supreme courts with extraordinary powers, as all first-instance courts were subjected to them. The interest of the administration in the efficiency of the institutions under conditions of growing workloading was proved by creating additional temporary departments. The main marker of domestic policy successes and failures of the Russian leadership at this stage was ensuring peace, the judicial system successfully coping with the task without introducing global reforms. However, the policy of the central authority in the region suffered substantial changes after the November Uprising of 1830-1831.

The documents of the Right-Bank judicial instances, reflecting the nuances of adaptation and adjustment of different judicial systems under the conditions of cumbersome imperial mechanism functioning, require to be further studied and introduced into the scientific circulation.

\section{BIBLIOGRAPHY}

Barmak M. (2007). Formation of the power institutions of the Russian Empire in the Right-Bank Ukraine (end of the 18th - first half of the 19th century): scientific publication. Ternopil: Aston, 512. [In Ukrainian].

Central State Historical Archives of Ukraine in Kyiv. F. 1254. Op. 1. D. 476.

Central State Historical Archives of Ukraine in Kyiv. F. 1254. Op. 1. D. 535. 
INTERMARUM: history, policy, culture. - Issue 6 .

Central State Historical Archives of Ukraine in Kyiv. F. 1254. Op. 1. D. 563.

Central State Historical Archives of Ukraine in Kyiv. F. 1254. Op. 1. D. 912.

Central State Historical Archives of Ukraine in Kyiv. F. 1254. Op. 1. D. 1018.

Central State Historical Archives of Ukraine in Kyiv. F. 1254. Op. 1. D. 1522.

Central State Historical Archives of Ukraine in Kyiv. F. 1254. Op. 1. D. 1555.

Central State Historical Archives of Ukraine in Kyiv. F. 1254. Op. 1. D. 1656.

Central State Historical Archives of Ukraine in Kyiv. F. 1582. Op. 1. D. 1.

Central State Historical Archives of Ukraine in Kyiv. F. 484. Op. 1. D. 9 .

Central State Historical Archives of Ukraine in Kyiv. F. 484. Op. 1. D. 82 .

Central State Historical Archives of Ukraine in Kyiv. F. 484. Op. 2. D. 13.

Central State Historical Archives of Ukraine in Kyiv. F. 484. Op. 2. D. 74 .

Complete collection of laws of the Russian Empire (1830). (Collection 2. Vol 1). St-Petersburg: In the printing house of the Second Branch of His Own Imperial Majesty's Chancery, 1379.

Complete collection of laws of the Russian Empire (1831). (Collection 2. Vol 6: Part 2). St-Petersburg: In the printing house of the Second Branch of His Own Imperial Majesty's Chancery, 360 .

Dolbilov M. (2010). Russian region, foreign faith: ethnoconfessional Imperial policy in Lithuania and Bielorussia. Moskow: NLO, 1000. [In Russian].

Gorizontov L. (1999). Paradoxes of imperial politics: Poles in Russia and Russians in Poland (XIX - early XX centuries). Moskow: Indrik, 272. [In Russian]. 
IНТЕРМАРУМ: історія, політика, культура. - Вип. 6.

Hurbyk A. (2009). Lublin Tribunal. In V. A. Smolii (Ed.), Encyclopedia of Ukrainian history (Vol. 6). Kyiv: Naukova dumka, 382. [In Ukrainian].

Ilin O. (2016). Changes in the judicial system on Ukrainian lands under Russian Empire in 1796 - 1801. Bulletin of the Kharkiv National University of Internal Affairs, 2, 23-28. [In Ukrainian].

Kappeler A. (2005). Russia as a multi-ethnic Empire: origin, history, disintegration. Lviv: Ukrainian Catholic University Press, 360. [In Ukrainian].

Karnishina N. (2012). The Western provinces of the Russian Empire: the issues of state and legal system. News of higher education institutions. Povolzhskiy region. the humanities, (1). 14-19. [In Russian].

Klochkov M. (1916). Essays on Government Activities of the Time of Paul I. Petrograd: Senate typography, 631. [In Russian].

Pavliuk V. (2010). The Polish aristocracy in the public life of Right-Bank Ukraine following the sections of the Polish-Lithuanian Commonwealth. Ukrainian historical journal, 3, 154-165. [In Ukrainian].

Pisarkova L. (2007). State administration of Russia from the end of the XVII to the end of the XVIII century. The evolution of the bureaucratic system. Moskow: ROSSPEN, 743. [In Russian].

Shcherbak N. (2017). Right-Bank Ukraine in the State-Legal System of the Russian Empire of the end of the XVIII - first half of the XIX century. Scientific Bulletin of the National Academy of Internal Affairs, (2), 288-297. [In Ukrainian].

Shevchuk A. (2018a). Volyn outer court (1798-1801): establishment, structure and activities. Problems of Ukrainian history in the early 19th and early 20th centuries (28), 179-202. [In Ukrainian].

Shevchuk A. (2018b). The Strife of Fiscal Inspectors and State Power for the Control of the Russian Empire Judicial System in Western Provinces (1799). Eminak: science quarterly journal, 4 (24), T. 1, 8286. [In Ukrainian].

Snaider T. (2012). The Reconstruction of Nations. Poland, Ukraine, Lithuania, Belarus, 1569-1999. Kyiv: Dukh i Litera, 460. [In Ukrainian]. 
INTERMARUM: history, policy, culture. - Issue 6.

Speranskiy M. (Ed.). (1830a) Complete collection of laws of the Russian Empire. (Collection 1. Vol 24). St-Petersburg: In the printing house of the Second Branch of His Own Imperial Majesty's Chancery, 869. [In Russian].

Speranskyi M. (red.). (1830b) Complete collection of laws of the Russian Empire. (Collection 1. Vol 25). St-Petersburg: In the printing house of the Second Branch of His Own Imperial Majesty's Chancery, 931. [In Russian].

Speranskyi M. (red.). (1830c) Complete collection of laws of the Russian Empire. (Collection 1. Vol 30). St-Petersburg: In the printing house of the Second Branch of His Own Imperial Majesty's Chancery, 1402. [In Russian].

Speranskyi M. (red.). (1830d) Complete collection of laws of the Russian Empire. (Collection 1. Vol 37). St-Petersburg: In the printing house of the Second Branch of His Own Imperial Majesty's Chancery, 981. [In Russian].

Speranskyi M. (red.). (1830e) Complete collection of laws of the Russian Empire. (Collection 1. Vol 44: Part 2). St-Petersburg: In the printing house of the Second Branch of His Own Imperial Majesty's Chancery, 410. [In Russian].

State Archive of Khmelnytskyi Region. F. 120. Op. 1. D. 766.

State Archive of Rivne Region. F. 550. Op. 1. D. 3.

State Archive of Vinnytsia Region. F. 514. Op. 1. D. 1.

Yesiunin S. (2016). Advocacy of Podolia during the integration period to Russian legal system in the late XVIII and first half of the XIX century (1793-1840). Education, science and culture on Podillia, (23), 240-253. [In Ukrainian].

\section{Шевчук Андрій. ГОЛОВНІ СУДИ ПРАВОБЕРЕЖНОЇ УКРАЇНИ (1797-1831): ТРАДИЦІЇ РЕЧІ ПОСПОЛИТОЇ ТА ІМПЕРСЬКІ ПРАКТИКИ}

\section{Анотація}

Мета роботи полягає у вивченні процесу заснування $і$ принципів організаиії роботи головних судів, на які в Правобережній Украйні покладалось здійснення ревізійно-апеляційних функиій. Одним із головних завдань статті є дослідження межі поступок та компромісів, на які готові були російські чиновники, пери за все у судовій сфері, заради здобуття лояльності польської шляхти. Хронологічно та територіально 
ІНТЕРМАРУМ: історія, політика, культура. - Вип. 6. ISSN 2518-7694 (Print) ISSN 2518-7708 (Online)

дослідження окреслено територіями колишніх «кресів» у період від кіния XVIII - до першої третини XIX cm.

Методологія дослідження базується на застосуванні принципів науковості, об'єктивності, історизму, системності. Для реалізайї поставлених завдань за допомогою порівняльного методу у статті проаналізовано особливості російської судової системи, яка через значну недосконалість змушена була зберігати елементи юридичних практик Речі Посполитої. Використання історико-системного, функиіонального та історико-порівняльного методів дозволили дослідити процес заснування та функиіонування головних судів, показати ситуаційну гнучкість верховної влади у задоволенні запитів місиевої еліти. Проаналізовано рівень ефективності діяльності судової інстаниї та ії оцінку з боку російської влади, місиевих чиновників та польської иляхти. Наукова новизна роботи полягає у дослідженні етапів створення та організаиіі діяльності головних судів у прочесі вибудовування стосунків між імперією та колишніми «кресами»в вонтексті адаптації судових систем. Наведено факти ситуативної гнучкості верховної влади у судовій сфері, що дозволяло мінімізувати сочіальну та політичну напругу в регіоні.

Відновлення Павлом I дії судів першої інстаниії, польської мови $i$ Третього Литовського статуту, стало підставою для досягнення консенсусу у стосунках між польською шляхтою та російською владою. Для забезпечення лояльності місиевої (польської) еліти цеентральна адміністрація проводила гнучку політику у судовій сфері, щуо разом зі збереженням власності і влади над кріпаками, примирило місиеву шляхту з російським пануванням. Шляхом створення губернських головних судів імперія планувала здійснювати корекиію діяльності судової системи заради мінімізаиії соціальної і політичної напруги. Кадровий склад судів свідчив про домінування польської еліти. Однак, обрані шляхтою на три роки до кожного департаменту голова $i$ три засідателі затверджувалися на посадах владою, та додатково контролювалися призначуваними радниками і секретарями. Було задоволено прагнення польської еліти у другорядних питаннях (двомовність, порядок судочинства і надання відпусток), але підпорядковано головним судам всю губернську судову систему. Для успішного функиіонування системи, за потреби, створювалися додаткові тимчасові департаменти. Маркером успіху внутрішньої політики було забезпечення спокою, з чим судова система успішно справлялася. Проте Листопадове польське повстання 1830-1831 рр. змінило політику центральної влади в регіоні. 


\section{INTERMARUM: history, policy, culture. - Issue 6. ISSN 2518-7694 (Print) ISSN 2518-7708 (Online)}

Ключові слова: Головні суди, Російська імперія, Правобережна Украӥна, губернський головний суд, судова система, польська шляхта, імперська лояльність

\section{Andrzej Szewczuk. SĄDY GLÓWNE PRAWOBRZEŻNEJ UKRAINY (1797-1831): TRADYCJE RZECZYPOSPOLITEJ POLSKIEJ I IMPERALNE PRAKTYKI}

\section{Streszczenie}

Celem pracy jest zbadanie procesu tworzenia i zasad organizacji pracy sadów głównych, którym w Prawobrzeżnej Ukrainie powierzono wykonywanie funkcji rewizyjnej $i$ apelacyjnej. Jednym $z$ głównych zadań artykulu jest zbadanie granic ustepstw i kompromisów, na które rosyjscy urzędnicy byli gotowi, przede wszystkim $w$ dziedzinie sadownictwa, żeby zdobyć lojalność polskiej szlachty. Przeglad chronologiczny i terytorialny określony jest terenami dawnych "Kresów" w okresie od końca XVIII do pierwszej trzeciej XIX wieku.

Metodologia badań opiera się na stosowaniu zasad naukowych, obiektywnych, historyzmu i systematyczności. Aby zrealizować te zadania metoda porównawcza, $w$ artykule przeanalizowano osobliwości rosyjskiego systemu sądowniczego, który z powodu znacznej niedoskonatości zmuszony byt zachować elementy praktyk prawnych Rzeczypospolitej Polskiej. Zastosowanie historyczno-systemowych, funkcjonalnych $i$ historycznoporównawczych metod umożliwito zbadanie procesu tworzenia $i$ funkcjonowania głównych sadów, wykazało elastyczność sytuacyjna władzy najwyższej $w$ zadowoleniu żąań lokalnej elity. Przeanalizowano poziom skuteczności działalności sadu i jego ocenę przez władze rosyjskie, lokalnych urzędników i polska szlachtę. Oryginalność naukowa pracy polega na zbadaniu etapów tworzenia i organizacji działalności sadów głównych $w$ procesie budowania stosunków między imperium a dawnymi "Kresami" $w$ kontekście adaptacji systemów sądowych. Przedstawione zostały fakty sytuacyjnej elastyczności najwyższej władzy w sferze sądowej, co pozwolito zminimalizować napięcia społeczne i polityczne $w$ regionie.

Przywrócenie przez Pawła I działań sąów pierwszej instancji, języka polskiego i III Statutu Litewskiego, byto podstawa do osiagnięcia konsensusu w sprawie stosunków między polska szlachta a władzami rosyjskimi. Aby zapewnić lojalność lokalnej (polskiej) elity, administracja centralna prowadziła elastyczna politykę sądowa, która wraz z zachowaniem własności $i$ władzy nad poddanymi pogodziła miejscowa szlachte z dominacja Rosji. Poprzez utworzenie głównych sadów gubernialnych imperium planowało zrealizować korekcję działalności systemu sadowniczego, aby 
IНТЕРМАРУМ: історія, політика, культура. - Вип. 6. ISSN 2518-7694 (Print)

ISSN 2518-7708 (Online)

zminimalizować napięcia społeczne i polityczne. Personel sądów świadczyt o dominacji polskiej elity. Jednak wybrani przez szlachte na trzy lata do każdego departamentu głowa $i$ trzej przysięgli zostali zatwierdzeni przez władze, a dodatkowo byli kontrolowani przez wyznaczonych doradców $i$ sekretarzy. Pragnienia polskiej elity $w$ drobnych sprawach (dwujęzyczność, postępowanie sadowe i urlop) zostaty spetnione, ale caty gubernialny system sadowy podlegat głównym sadom. Dodatkowe tymczasowe dziaty zostaty utworzone $w$ razie potrzeby dla skutycznego działania systemu. Określeniem sukcesu polityki wewnętrznej było zabezpieczenie spokoju, z czym system sadowy świetnie sobie radzit. Jednak polskie powstanie listopadowe w latach 1830-1831 zmienito politykę rzadu centralnego w regionie.

Stowa kluczowe: sądy główne, imperium rosyjskie, Prawobrzeżna Ukraina, gubernialny sąd główny, system sądowy, polska szlachta, lojalność imperalna.

The article was received 08.30.2019 Article recommended for publishing 09.27.2019 